Sains Malaysiana 49(12)(2020): 3073-3080

http://dx.doi.org/10.17576/jsm-2020-4912-19

\title{
Effect of Temperature on Strain-Induced Hardness of Lead-Free Solder Wire using Nanoindentation Approach
}

\author{
(Kesan Suhu terhadap Kekerasan Terikan Teraruh Wayar Pateri Bebas Plumbum menggunakan Pendekatan
} Pelekukan Nano)

NORLIZA ISMAIL, MARIA ABU BAKAR* \& SAIFUl BAHARI BAKARUdiN

\begin{abstract}
Hardness properties of SAC305 solder wire under tensile test at varied temperature was investigated. Continuous multicycle (CMC) nanoindentation technique with ten cycle of indentation for each sample was performed to evaluate the hardness behaviour of SAC305 solder wire at different depth of indentation. As a result, all investigated SAC305 solder wire under constant strain rate of tensile test and at different temperature revealed the occurrence of indentation size effect (ISE). At initial cycle of indentation, SAC305 solder wire at room temperature $\left(25^{\circ} \mathrm{C}\right)$ have higher hardness value compared to the others sample which exposed to the varied temperature during tensile test. Besides, higher temperature causes the higher strain or elongation to the SAC305 solder wire. Applied of strain during the tensile test had generated the pre-dislocation activity in the SAC305 solder wire. Therefore, higher hardness values of SAC305 at room temperature is due to the existence of high dislocation density induced by the applied strain. Nevertheless, the existence of heat at 60, 90, 120 and $180^{\circ} \mathrm{C}$ during the tensile test prompt the rearrangement of dislocation and reduce the dislocation activities, thus, allowing higher elongation of solder wire.
\end{abstract}

Keywords: Continuous multi-cycle nanoindentation; hardness; lead-free solder; strain-induced; tensile test

ABSTRAK

Sifat kekerasan wayar pateri SAC305 di bawah ujian tegangan pada suhu yang berbeza telah dikaji. Teknik pelekukan nano multi-kitaran berterusan dengan sepuluh kitaran pelekukan bagi setiap sampel telah dijalankan untuk menilai kelakuan kekerasan wayar pateri SAC305 pada kedalaman pelekukan yang berbeza. Keputusannya, kesemua wayar pateri SAC305 yang dikaji di bawah kadar terikan yang malar dan pada suhu yang berbeza menunjukkan berlaku kesan saiz pelekukan (ISE). Pada kitaran awal pelekukan, wayar pateri SAC305 pada suhu bilik (25 ${ }^{\circ}$ C) mempunyai nilai kekerasan yang lebih tinggi dibandingkan dengan sampel lain yang didedahkan kepada suhu yang berbeza semasa ujian ketegangan. Suhu yang lebih tinggi menyebabkan terikan atau pemanjangan yang lebih tinggi terhadap wayar pateri SAC305. Terikan yang dikenakan semasa ujian tegangan telah menghasilkan aktiviti prakehelan pada wayar pateri SAC305. Oleh itu, nilai kekerasan yang lebih tinggi pada wayar pateri SAC305 pada suhu bilik adalah disebabkan oleh kehadiran ketumpatan kehelan yang tinggi teraruh oleh terikan yang dikenakan. Walau bagaimanapun, kehadiran haba pada suhu 60, 90, 120 dan $180^{\circ} \mathrm{C}$ ketika ujian tegangan menyebabkan penyusunan semula kehelan dan mengurangkan aktiviti kehelan serta membenarkan pemanjangan wayar pateri yang lebih tinggi.

Kata kunci: Kekerasan; pateri bebas-plumbum; pelekukan nano multi-kitaran berterusan; terikan-teraruh; ujian tegangan

\section{INTRODUCTION}

Hardness is defined as the resistance of a material to local plastic deformation attained by indentation or penetration of a predetermined geometry indenter onto a flat surface of metal under predetermined load (Faraji et al. 2018; Ismail et al. 2019). Hardness properties evaluate the performance of materials and information of material hardness very important in structural, aerospace, quality control, automotive, failure analysis, and several other forms of industry and manufacturing (Ismail et al. 2020). Hardness is dependent on ductility, elastic stiffness, plasticity, strain, strength, toughness viscoelasticity, and viscosity 
(Armstrong \& Elban 2012; Di Gianfrancesco 2017). Information of hardness can be obtained from hardness testing which is comparatively easy to perform and is typically completely or minimally non-destructive and inexpensive instrumentation when compared to other types of material testing equipment. Hardness test commonly applied to obtain the direct information regarding the materials resistance towards the deformation. Common conventional hardness test that was used since a long years ago are known as Vickers micro hardness and Brinell micro hardness (Walley 2012; Wan Yusoff et al. 2019). Development of nanoindentation then, become as one of approach on evaluation of mechanical properties of materials included hardness.

Nanoindentation has been recognized as a powerful tool technique for measuring mechanical properties at nano and micro-scale. From load-depth nanoindentation profile data, hardness values of indented material can be extracted (He \& Swain 2017; Jalar et al. 2020). Nanoindentation has lately gained a great attention in solder alloy characterization. An advancement of the nanoindentation technique depends on the utilization of a fine indenter tip (down to $20 \mathrm{~nm}$ ), along with dynamic load control capability. Most of the hardness evaluations on lead-free solders by nanoindentation are generally associated with the fine Berkovich diamond indenter. This is because such an indenter type is the most common equipment from current manufacturers (Abdullah et al. 2018; Song et al. 2009). Briefly, nanoindentation provides an in-depth hardness evaluation of lead-free solder alloys. Nanoindentation can offer the localized measurement such as the ability to carry out individual hardness measurement on specific intermetallic compound (IMC) phases in solder matrix (Yahaya \& Mohamad 2017). The best thing that nanoindentation offers is another additional analysis part called cyclic nanoindentation test or also known as continuous multicycle (CMC) nanoindentation test. Commonly, only single indentation can be applied in standard micro hardness test like Vickers and Brinell. In $\mathrm{CMC}$ nanoindentation, sample is reloaded immediately to even higher loads/depth than the previous loading cycle. Hardness changes or behaviour can be observed via CMC nanoindentation. CMC nanoindentation could be used to effectively extract certain sensitive information about material behaviour such as surface response to the plastic deformation due to external load at the same indentation location and different depth (Li \& Bhushan 2002; Saraswati et al. 2006).

During the last decade, bulk nanostructured materials or materials with submicron structure produced by severe plastic deformation have been studied, as well as their microstructure development and its relation to mechanical properties. Plastic deformation usually initiated by induced certain level of strain by various technique such as high-pressure torsion and hot rolled. Studies on strain induced plastic deformation in alloys becomes one approach to improve the mechanical performance of material by understanding the deformation mechanism involved. Panigrahi et al. (2009) investigated the effect of severe plastic deformation on mechanical properties of aluminium alloy $\mathrm{Al} 6063$ subjected to rolling at cryogenic temperature and room temperature. They found that at certain deformed conditions, significantly improve the mechanical properties such as hardness and yield strength. Onuki et al. (2018) conducted time-of-flight neutron diffraction experiment to study the mechanisms of plastic deformation in strain induced rolled-Co based alloys. They found that, dislocation densities of the matrix phases of Co based alloys increased similarly with the increasing in the rolling reduction.

In this study, strain induced plastic deformation was introduced to the SAC305 lead-free solder wire at varied temperature. Hardness properties which response to the surface deformation behaviour was analysed using continuous multicycle (CMC) nanoindentation. Samples were deformed at room temperature and high temperature subjected to constant strain rate until failure. Hardness and deformation behaviour of deformed solder wire further discussed.

\section{Materials AND METHOdS}

In this study, $\mathrm{Sn}-3.0 \mathrm{Ag}-0.5 \mathrm{Cu}$ (SAC305) lead-free solder wires was go through the tensile test followed by nanoindentation test. SAC305 solder wire was provided by Red Ring Solder (M) Sdn. Bhd. and have approximate melting point of $\sim 215{ }^{\circ} \mathrm{C}$. The SAC305 solder wire was cut into lengths of $100 \mathrm{~mm}$ and epoxy resin were attached within $25 \mathrm{~mm}$ of each end of the wire as shown in Figure 1. Attachment of epoxy resin to the both end of the solder wire is to avoid the deformation to solder wire by the gripper. Tensile tests were conducted by using Instron testing machine (Instron 5564 Universal Testing Machine) at different chamber temperatures of room temperature $\left(25^{\circ} \mathrm{C}\right), 60,90,120$, and $180^{\circ} \mathrm{C}$. Load cell applied for this test is $1 \mathrm{kN}$ and strain rate was set up at $0.1 \mathrm{mms}^{-1}$. After the tensile test, all tested SAC305 solder wire underwent sample preparation before going through nanoindentation test. Selected area of tensile test samples was cutted into $20 \mathrm{~mm}$ of length. The cutted area was chosen far from the necking area. Samples were then undergoing the mounting process before grounded with 600,800 , and 1200 grit silicon carbide (SiC) abrasive papers. Then, polishing process was conducted by using the silk polishing cloth with $3 \mu \mathrm{m}$ and $1 \mu \mathrm{m}$ of diamond spray suspension. 


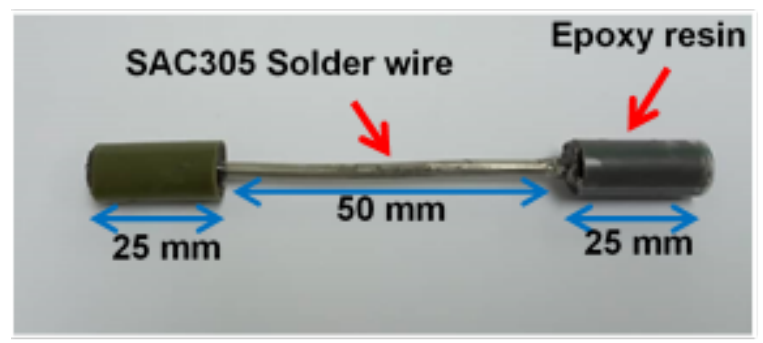

FIGURE 1. SAC305 solder wire with the attachments of epoxy resin

Nanoindentation test was performed using Micro Materials Nano Test P3 system equipped with a Berkovich diamond tip. Continuous multi-cycle nanoindentation (CMC) was performed with ten cycles of indentation up to $10 \mathrm{mN}$ load. First indentation starts with $1 \mathrm{mN}$ load then followed by next indentation or cycle with the increasing of $1 \mathrm{mN}$ load. Nanoindentation testing was performed at room temperature of $25^{\circ} \mathrm{C}$ with loading and unloading rates of $0.1 \mathrm{mNs}^{-1}$ and total dwell time of $60 \mathrm{~s}$. The data was obtained from the nanoindentation test according to the Oliver and Phar (1992) method. This method determines the value of hardness based on the depth sensing indentation of load-indentation displacement data.

\section{RESULTS AND DisCUSSION}

Figure 2 shows the stress versus strain curve for SAC305 solder wire at variation temperature obtained from the tensile test. This stress-strain curve showed the different profile due to expose to the different temperature during the tensile test. Material used in this study was a Pb-free solder of Sn-based alloy. The melting point of this alloy is approximately $\sim 215^{\circ} \mathrm{C}$. The temperature used up to $180^{\circ} \mathrm{C}$. The stress-strain behaviour followed the typical trend for soft metal (Padilla et al. 2012; Wong et al. 2008). The ultimate tensile strength (UTS) values decrease with increasing temperature and elongation or strain at failure increase with temperature.

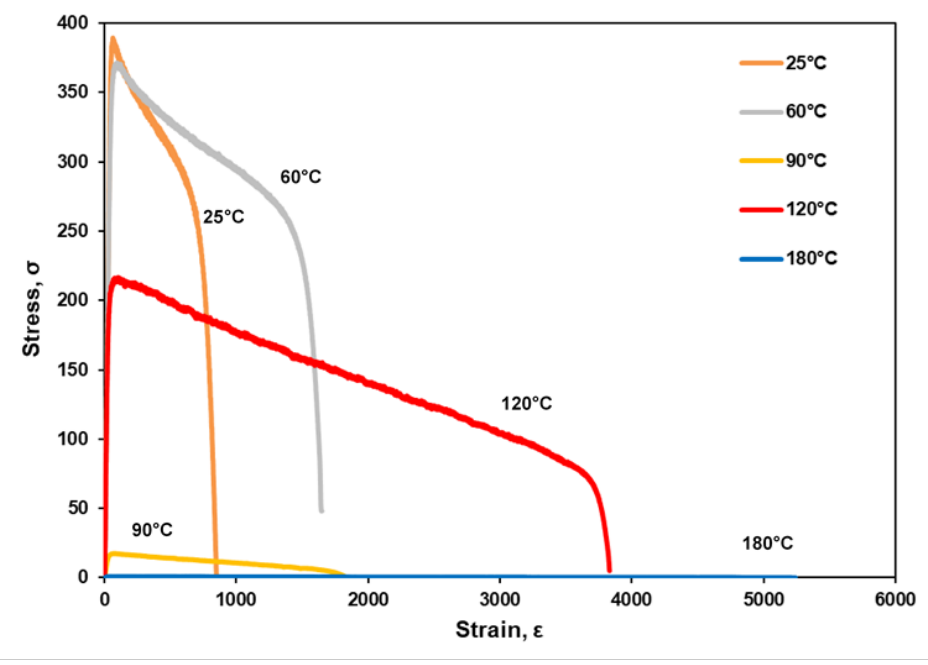

FIGURE 2. Stress versus strain curve of SAC305 solder wire at varied temperature

Table 1 indicates the values of UTS and strain at failure for SAC305 solder wire at varied temperature. On the plastic region, the stress values are dropped significantly for $25^{\circ} \mathrm{C}$ sample and $60^{\circ} \mathrm{C}$ sample. For 90 ,
120 and $180^{\circ} \mathrm{C}$ samples, larger elongation was observed. This is in line with recrystallization temperature and related dislocation activities on soft material with low melting point (Abdullah et al. 2019). 
TABLE 1. Ultimate tensile strength (UTS) and strain at failure for investigated SAC305 solder wire at varied temperature

\begin{tabular}{ccc}
\hline Temperature $\left({ }^{\circ} \mathrm{C}\right)$ & UTS $(\mathrm{MPa})$ & Strain $(\varepsilon)$ at failure \\
\hline 25 & 389.00 & 876 \\
60 & 367.00 & 1646 \\
90 & 17.34 & 1837 \\
120 & 216.00 & 3825 \\
180 & 0.87 & 5241 \\
\hline
\end{tabular}

Hardness behaviour of tensile test SAC305 solder wires were extensively discussed from continuous multi-cycle (CMC) nanoindentation data. The CMC nanoindentation test results are shown in Figures 3 and 4. Figure 3 is the $P$ - $h$ profiles of indentation for each SAC 305 solder wire samples at varied temperature. There are ten cycle or indentation for each sample as indicated in Figure 3(a). Each cycle shows the loading, dwell time and unloading process as can be seen in a single indentation technique. Constant load at $1 \mathrm{mN}$ is applied to every cycle up to $10 \mathrm{mN}$. Indentation depth increase with the increasing of indentation cycle. Nanoindentation hardness is defined as the indentation load divided by the projected contact area of the indentation. It is the mean pressure that a material can support under load (Li \& Bhushan 2002). From the $P$ - $h$ profile of CMC nanoindentation, hardness values can be obtained by applied the following equation.

$$
H=\frac{P_{\max }}{A}
$$

where $P_{\max }$ is maximum load, and $A$ is the projected contact area.

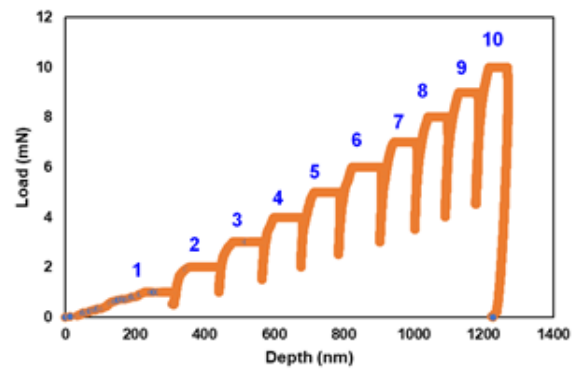

(a)

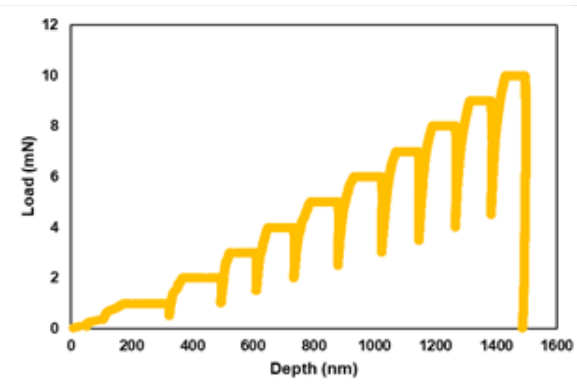

(c)

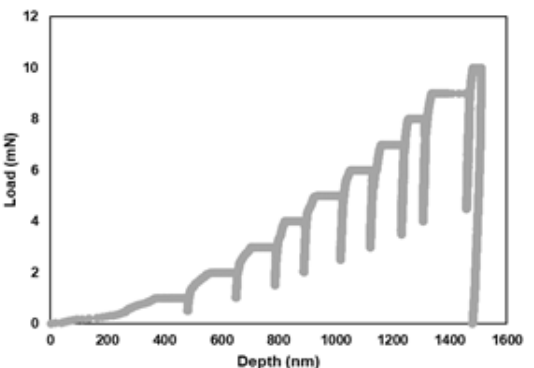

(b)

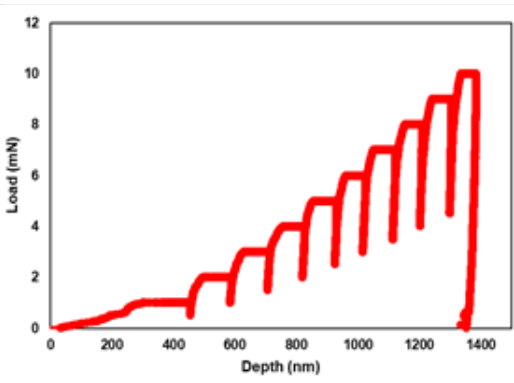

(d)

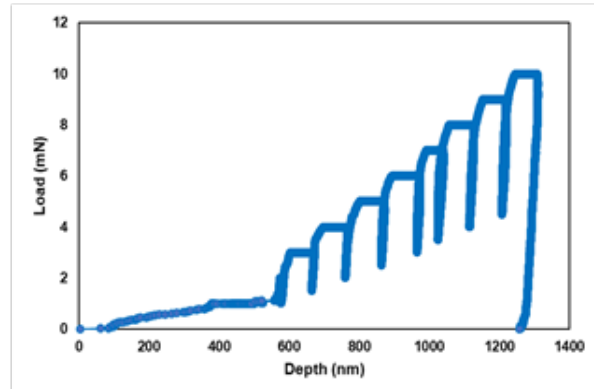

(e)

FIGURE 3. $P$ - $h$ profile of continuous multi-cycle nanoindentation for investigated SAC305 solder wire (a) $25^{\circ} \mathrm{C}$ (b) $60{ }^{\circ} \mathrm{C}$ (c) $90{ }^{\circ} \mathrm{C}$ (d) $120^{\circ} \mathrm{C}$, and (e) $180{ }^{\circ} \mathrm{C}$ tensile test samples 
Figure 4 indicates the hardness values of investigated samples for $\mathrm{CMC}$ nanoindentation at variation temperature. Ten cycle of indentation resulted in the ten values of hardness for each sample. There are obviously can be seen that the variation of hardness values with the indentation depth for each sample. Different hardness values at different indentation depth showed that, all investigated samples experienced the indentation size effect (ISE). ISE usually occurred due to the dependent of hardness properties to the applied indentation test load (Bhattacharya et al. 2019).

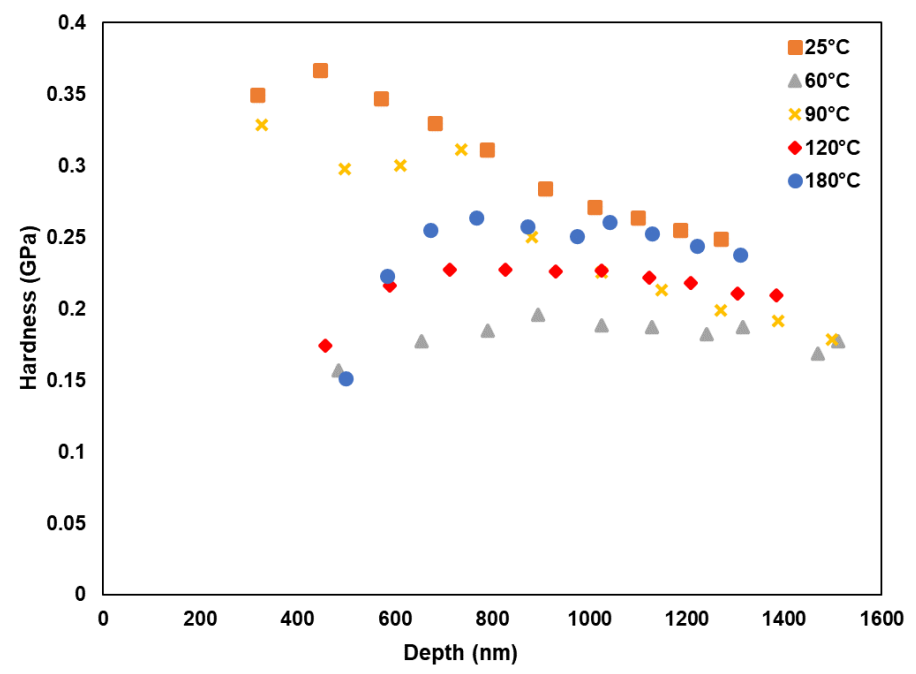

FIGURE 4. Variation of hardness with indentation depth for investigated solder

Figure 5 illustrates the typical hardness-indentation depth curve and related ISE that usually occurred during the continuous multi-cycle nanoindentation. Generally, there are three regions occurred which is reverse indentation size effect (RISE), indentation size effect (ISE) and non-region of ISE (Wang et al. 2019). RISE region occurred when the hardness value increase with the increasing of applied test load meanwhile ISE occurred when the hardness value decrease with the increasing of applied test load (Sangwal 2000).

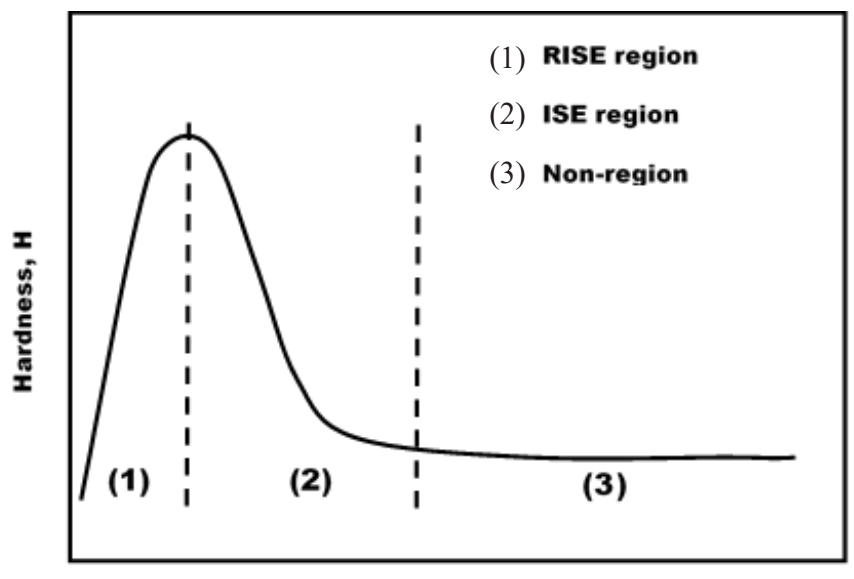

Indentation depth, h

FIGURE 5. Typical hardness-displacement curve showing three recognized regions 
In the current study, SAC305 solder wire under constant applied strain rate and variation of temperature followed the RISE behaviour at the initial cycle of indentation before following the ISE behaviour and then reach the steady state or non-ISE region. At the initial cycle of indentation, penetration of indenter tip attributed to the local increase of geometrically necessary dislocations
(GND) (Kim et al. 2017). Existence of GND increase the stress flow of material and increase the hardness value. Deeper penetration of indenter tip decreases the GND density until reach the steady state where the hardness value dependent on statistically stored dislocation (SSD). Figure 6 indicates the schematic of generated GND by penetration of indenter tip.

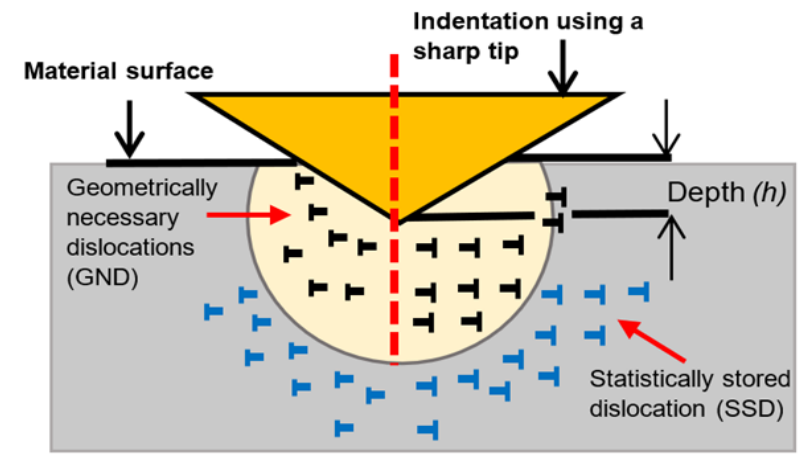

(Maharaj \& Bhushan 2014)

FIGURE 6. Schematic of generated geometrically necessary dislocations (GNDs) by penetration of indenter tip

Based on Figure 4, at initial cycle of indentation, hardness value of room temperature sample is higher than hardness values of others investigated sample. Although the applied strain rate and loading rate are constant, different testing temperature during the tensile test affect the hardness values. Higher temperature resulted to the lower values of hardness at initial cycle of indentation or at RISE region. When reach to the ISE region, SAC305 solder wire at room temperature has a higher slope compared to others. Higher the temperature contributed to the lower slope of hardness at ISE region. Existence of heat not only affects the strain or elongation of the solder wire but also influence the hardness behaviour of solder wire (Htun et al. 2008). During the tensile, applied of strain generate the formation of dislocation. When strain was applied with the existence of heat, it may cause the rearrangement of dislocation and allow the elongation of solder wire (Ivanov et al. 2020). Higher hardness of room temperature solder wire sample is due to the higher dislocation activity occurred during the tensile test opposite with the solder wire exposed to heat that have lower dislocation activity ( $\mathrm{Li}$ et al. 2000). To investigate the effect of temperature on hardness due to the cycles test, hardness values were plotted against temperature of tensile test condition, as shown in Figure 7. Obviously, temperature play a role in factor affecting the hardness values, such as dislocation activities. It is generally accepted that re-arrangement of crystallographic imperfection such as dislocation activities can be appeared due to thermally activated process (Luo et al. 2019).

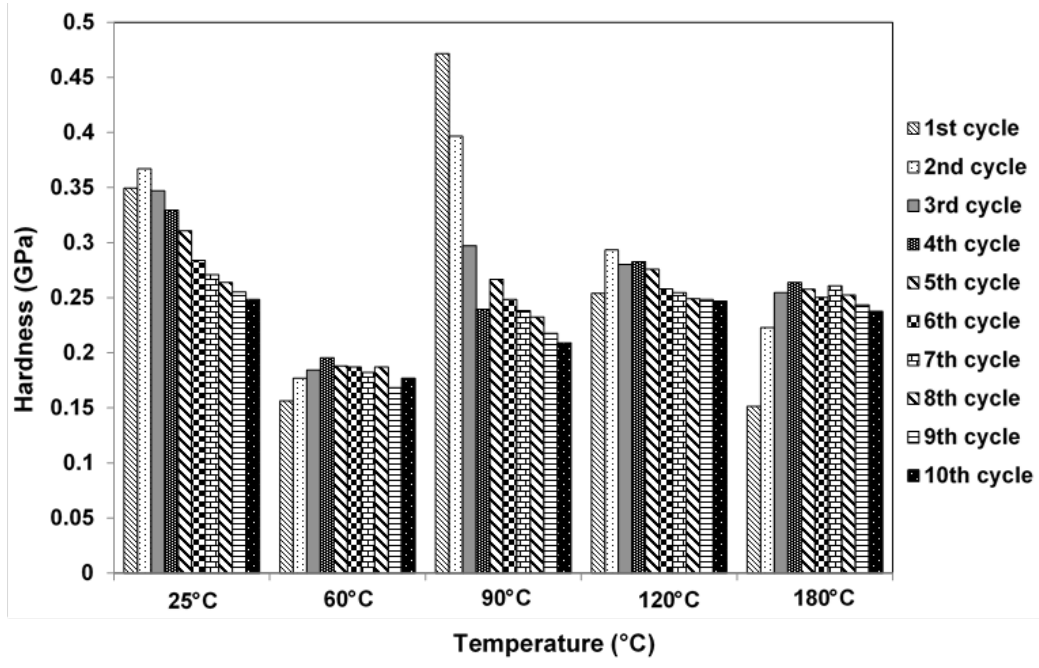

FIGURE 7. Hardness values of ten cycle indentation for investigated samples at variation temperature 


\section{CONCLUSION}

This work was devoted to evaluate the strain-induced hardness behaviour of SAC305 solder wire at varied temperature by continuous multi-cycle (CMC) nanoindentation. Hardness values of SAC305 solder wire were influenced by the applied strain and the variation of testing temperature during the tensile test. Higher temperature produced the higher strain on SAC305 solder wire. Higher strain produced the lower slope at ISE region before it reaches to the steady state region of the hardness versus depth graph. It was found that continuous multi-cycle nanoindentation was able to investigate the strain-induced hardness behaviour.

\section{ACKNOWLEDGEMENTS}

The authors are gratefully acknowledged the financial support from the Ministry of Education, Malaysia under FRGS/1/2019/STG07/UKM/03/1 and Universiti Kebangsaan Malaysia (UKM) under MI-2018-019 grant and Redring Solder (M) Sdn. Bhd. for research materials and collaboration work.

\section{REFERENCES}

Abdullah, I., Zulkifli, M.N., Jalar, A., Ismail, R. \& Ambak, M.A. 2019. Relationship of mechanical and micromechanical properties with microstructural evolution of $\mathrm{Sn}-3.0 \mathrm{Ag}-0.5 \mathrm{Cu}$ (SAC305) solder wire under varied tensile strain rates and temperatures. Journal of Electronic Materials 48(2019): 2826-2839.

Abdullah, I., Zulkifli, M.N., Jalar, A. \& Ismail, R. 2018. Deformation behavior relationship between tensile and nanoindentation tests of SAC305 lead-free solder wire. Soldering and Surface Mount Technology 30(3): 194-202.

Armstrong, R.W. \& Elban, W.L. 2012. Hardness properties across multiscales of applied loads and material structures. Materials Science and Technology 28(9-10): 1060-1071.

Bhattacharya, S., Kundu, R., Bhattacharya, K., Poddar, A. \& Roy, D. 2019. Micromechanical hardness study and the effect of reverse indentation size on heat-treated silver doped zincmolybdate glass nanocomposites. Journal of Alloys and Compounds 770: 136-142.

Di Gianfrancesco, A. 2017. The fossil fuel power plants technology. Materials for Ultra-Supercritical and Advanced Ultra-Supercritical Power Plants, edited by Di Gianfrancesco, A. London: Woodhead Publishing. pp. 1-49.

Faraji, G., Kim, H.S. \& Kashi, H.T. 2018. Mechanical properties of ultrafine-grained and nanostructured metals. In Severe Plastic Deformation, edited by Faraji, G., Kim, H.S. \& Kashi, H.T. London: Elsevier. pp. 223-257.

He, L.H. \& Swain, M.V. 2017. 3.9 Microindentation. Comprehensive Biomaterials II, edited by Paul Ducheyne, Amsterdam: Elsevier. pp. 144-168.

Htun, M.S., Kyaw, S.T. \& Lwin, K.T. 2008. Effect of heat treatment on microstructures and mechanical properties of spring steel. Journal of Metals, Materials and Minerals 18(2): 191-197.
Ismail, N., Jalar, A., Abu Bakar, M., Safee, N.S., Wan Yusoff, W.Y. \& Ismail, A. 2020. Microstructural evolution and micromechanical properties of SAC305/CNT/CU solder joint under blast wave condition. Soldering \& Surface Mount Technology Vol. ahead-of-print. No. https://doi.org/10.1108/ SSMT-11-2019-0035.

Ismail, N., Jalar, A., Bakar, M.A., Ismail, R., Safee, N.S., Ismail, A.G. \& Ibrahim, N.S. 2019. Effect of isothermal aging on microhardness properties of $\mathrm{Sn}-\mathrm{Ag}-\mathrm{Cu} / \mathrm{CNT} / \mathrm{Cu}$ using nanoindentation. Sains Malaysiana 48(6): 1267-1272.

Ivanov, I.V., Emurlaev, K.I., Lazurenko, D.V., Stark, A. \& Bataev, I.A. 2020. Rearrangements of dislocations during continuous heating of deformed $\beta$-TiNb alloy observed by in-situ synchrotron X-ray diffraction. Materials Characterization 166: 1-9.

Jalar, A., Bakar, M.A. \& Ismail, R. 2020. Temperature dependence of elastic-plastic properties of fine-pitch SAC 0307 solder joint using nanoindentation approach. Metallurgical and Materials Transactions A: Physical Metallurgy and Materials Science 51(3): 1221-1228.

Kim, Y.C., Gwak, E.J., Ahn, S.M., Jang, J.I., Han, H.N. \& Kim, J.Y. 2017. Indentation size effect in nanoporous gold. Acta Materialia 138(2017): 52-60.

Li, Q., Xu, Y.B., Lai, Z.H., Shen, L.T. \& Bai, Y.L. 2000. Dynamic recrystallization induced by plastic deformation at high strain rate in a Monel alloy. Materials Science and Engineering A 276(1-2): 250-256.

Li, X. \& Bhushan, B. 2002. A review of nanoindentation continuous stiffness measurement technique and its applications. Materials Characterization 48(1): 11-36.

Luo, F., Peng, H., Chen, H., Xiao, X., Xie, W., Wang, H. \& Yang, B. 2019. Dislocation substructure-controlled softening of Cu20Ni-20Mn alloy. Materials Characterization 147: 253-261.

Maharaj, D. \& Bhushan, B. 2014. Scale effects of nanomechanical properties and deformation behavior of Au nanoparticle and thin film using depth sensing nanoindentation. Beilstein Journal of Nanotechnology 2014(5): 822-836.

Oliver, W.C. \& Pharr, G.M. 1992. An improved technique for determining hardness and elastic modulus using load and displacement sensing indentation experiments. Journal of Materials Research 7(6): 1564-1583.

Onuki, Y., Sato, S., Nakagawa, M., Yamanaka, K., Mori, M., Hoshikawa, A., Ishigaki, T. \& Chiba, A. 2018. Strain-induced martensitic transformation and texture evolution in coldrolled Co-Cr alloys. Quantum Beam Science 2(2): 1-11.

Padilla, E., Jakkali, V., Jiang, L. \& Chawla, N. 2012. Quantifying the effect of porosity on the evolution of deformation and damage in Sn-based solder joints by X-ray microtomography and microstructure-based finite element modeling. Acta Materialia 60(9): 4017-4026.

Panigrahi, S., Rengaswamy, J. \& Pancholi, V. 2009. Effect of plastic deformation conditions on microstructural characteristics and mechanical properties of $\mathrm{Al} 6063$ alloy. Materials and Design 30(6): 1894-1901.

Sangwal, K. 2000. On the reverse indentation size effect and microhardness measurement of solids. Materials Chemistry and Physics 63(2): 145-152.

Saraswati, T., Sritharan, T., Mhaisalkar, S., Breach, C.D. \& Wulff, F. 2006. Cyclic loading as an extended nanoindentation 
technique. Materials Science and Engineering A 423(1-2): 14-18.

Song, J.M., Shen, Y.L., Su, C.W., Lai, Y.S. \& Chiu, Y.T. 2009. Strain rate dependence on nanoindentation responses of interfacial intermetallic compounds in electronic solder joints with $\mathrm{Cu}$ and $\mathrm{Ag}$ substrates. Materials Transactions 50(5): 1231-1234.

Walley, S.M. 2012. Historical origins of indentation hardness testing. Materials Science and Technology 28(9-10): 10281044.

Wan Yusoff, W.Y., Ismail, N., Safee, N.S., Ismail, A., Jalar, A. \& Abu Bakar, M. 2019. Correlation of microstructural evolution and hardness properties of $99.0 \mathrm{Sn}-0.3 \mathrm{Ag}-0.7 \mathrm{Cu}$ (SAC0307) lead-free solder under blast wave condition. Soldering and Surface Mount Technology 31(2): 102-108.

Wang, L., Asempah, I., Li, X., Zang, S.Q., Zhou, Y.F., Ding, J. \& Jin, L. 2019. Indentation size effect in aqueous electrophoretic deposition zirconia dental ceramic. Journal of Materials Research 34(4): 555-562.

Wong, E.H., Selvanayagam, C.S., Seah, S.K.W., van Driel, W.D., Caers, J.F.J.M., Zhao, X.J., Owens, N., Tan, L.C., Frear, D.R., Leoni, M., Lai, Y.S. \& Yeh, C.L. 2008. Stress-strain characteristics of tin-based solder alloys at medium strain rate. Materials Letters 62(17-18): 3031-3034.

Yahaya, M.Z. \& Mohamad, A.A. 2017. Hardness testing of lead-free solders: A review. Soldering and Surface Mount Technology 29(4): 203-224.

Norliza Ismail

Department of Applied Physic

Faculty of Science \& Technology

Universiti Kebangsaan Malaysia

43600 UKM Bangi, Selangor Darul Ehsan

Malaysia

Norliza Ismail, Maria Abu Bakar* \& Saiful Bahari Bakarudin Institute of Microengineering and Nanoelectronics (IMEN)

Universiti Kebangsaan Malaysia

43600 UKM Bangi, Selangor Darul Ehsan

Malaysia

*Corresponding author; email: maria@ukm.edu.my

Received: 18 August 2020

Accepted: 28 August 2020 